\title{
Geophysical and Hydrological Parameters of an Opposite Flow of Water 'Ultapani' at Bisarpani, Kamaleshwarpur, Mainpat Plateau Surguja CG, India
}

\author{
Hiran Das Mahar*, Ram Bai Mahar \\ R G Govt. P G Auton. College Ambikapur, Surguja, CG, 497001, India \\ Corresponding Author Email: drhdmahar@gmail.com
}

https://doi.org/10.18280/mmc_c.802-402

Received: 22 March 2019

Accepted: 17 May 2019

\author{
Keywords: \\ opposite water flow, flow against gravity, ascent \\ of water flow, anti-gravity flow, ultapani, \\ bisarpani
}

\begin{abstract}
An exploration was done to study the reverse water flows called 'Ultapani' in village Bisarpani, Kamleshwarpur, Mainpat, Surguja, Chhattisgarh, India. The water flow ascents $14 \mathrm{~m}$. at that place against gravity force. Geophysical parameters like length, width, height and magnetic intensity, gravity, altitude and slope of Ultapani were measured along with hydrological parameters like flow velocity, flow perimeter, depth of flow, total height of wall, and force of flow of Ultapani at Village Bisarpani (forgetwater). Trigonometry on ascent height and applied force calculations on these specific geophysics were discussed.
\end{abstract}

\section{INTRODUCTION}

Geo diversity might be geo morphological or geophysical specification [1]. Bernoulli's principle, Siphon's theory and Venturi effect are studied for upward flow in hydrology in relation with given passage or with geomorphology. While, Archimedes principle of floating by buoyancy force, $\mathrm{F}=$ d.v.g, is studied for stable water body in relation with floating object on or in it. Water flow velocity in river is in relation with slope and reverse of width. But due to certain geophysics, and natural activity, reverse flow is seen. Exempli gratia, River Ganga flows opposite due to ocean wave force at Kolkata WB India. Such miracle is also reported that up to small distance, rivers flow opposite, anti-gravity, like another Ultapani at Kokrajhar in Assam, India. It is situated $55 \mathrm{~km}$ away from Kokrajhar, Holtugaon Forest Division of Manas Biosphere reserve with full, richness of biodiversity and tourism of Ultapani Reserve Forest [2-5].

An uphill flow under an ice layer in Antarctica is discovered as a "Mysterious green ice spotted in Antarctica by NASA's Operational Land Imager!" It is a wave site showing detail description and video of this beautiful phenomenon. A mysterious feature of green ice has been spotted in Antarctica's Granite Harbor, a bay of the coast of Victoria Land, which spreads over an area of $26 \mathrm{~km}$ located in the Ross Sea. The photos of the Operational Land Imager (OLI) on Land sat 8 were taken on March 5, 2017. By Jan Lieser, a marine glaciologist from Australia's Antarctic Climate and Ecosystems Cooperative Research Center [6, 7]. There could be more such opposite rivers. Before being river all springs upward moves but atm. pressure, liquidity nature and gravity force make water flow toward slope. But uphill movement of water flow of open water current is up to limited distance; secondly, there are some gravity holes on earth where, even a geo scientist might surprise to visit to study suspended stones [7, 8].

Objective of the paper was to explore geosciences of reverse flow of water and measure it's geophysical and hydrological parameters and find out possible cause to ascent water current against gravitational force of Ultapani at Bisarpani village.

Figure 1 represents street map of reverse water flows called 'Ultapani' in village Bisarpani, Kamleshwarpur, Mainpat, Surguja, Chhattisgarh, Postal Index $\mathrm{N}^{0}$ 497111, India. GPS coordinates- Lat.22.878088999, Long. 83.281316199999 and Altitude 3203 feet to 3249 feet. Utapani is located between Darima (below Mainpat) and Jaljali (on Mainpat Plateau) [9$11]$.

\section{METHODOLOGY}

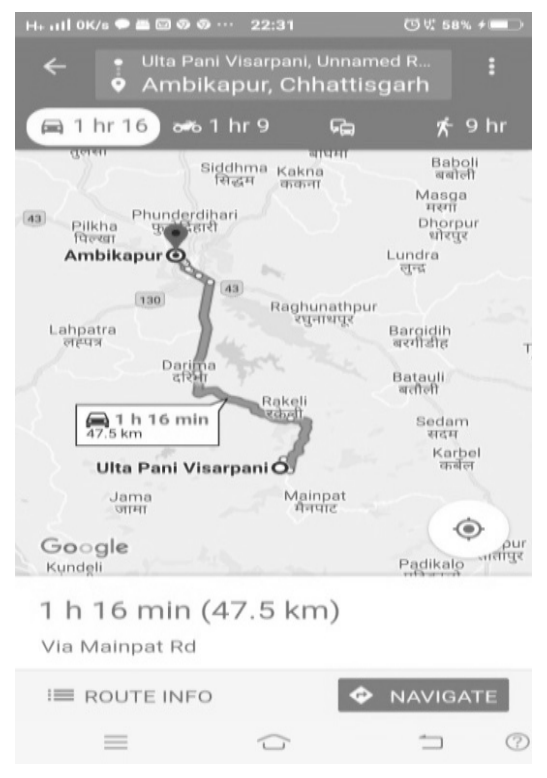

Figure 1. Street map of Ultapani

Authors arranged meter tap, thread, 4 keels, telescope, gonometer, one bottle water, steles meter tape (for flow perimeter), digital weight handbook 500 gram and Unitop Multimeter. Digital altimeter, slope meter, GPS, speedometer, 
barometer, hygrometer, gravity meter and magnetic compass were downloaded. Methodology for measurement of height of Ultapani using altimeter and construction of temporary Sextant are described in reference 15. Calibration of mini electronic weight box 'Hand book 500 grams' was made in practice.

For the exploration of Ultapani Figure 1 was followed. The exploration of 'Ultapani' was conducted, approximately 47.4 $\mathrm{Km}$. away from Ambikapur, the head quarter of Surguja division, on national highway $\mathrm{N}^{\circ} 43$ in east - south direction. It was done in hot summer (20 May and 01 June. 2019) at the environmental temp. $37^{\circ}$ to $40^{\circ} \mathrm{C}$. Started from Ambikapur on Raigarh road (NH-43), just after $01 \mathrm{Km}$. it is bifurcated. We followed right side on Damali road in east - south direction. Passing through Darima $13 \mathrm{Km}$ east turn was taken on Mainpat road crossing Machhali river before $22 \mathrm{~km}$ to Mainpat, geological data like gravity, altitude, magnetic field intensity, atm. pressure, \% moisture etc were noted, then Mainpat plateau was ascended with $30^{\circ}-35^{\circ}$ degree steep, with 62 curves reached to the side road before $3 \mathrm{~km}$ of Ultapani. There geological parameters are noted then west direction driving car reached to Ultapani at Bisarpani village.

Effect of external water, soil and stone were tested. Length, width, water flow velocity, water perimeter, angle of flow up side, etc. were manually measured and height from origin, altitude, magnetic field intensity, gravity and slope were measured by digital meters using android cell phone.

Table 1 represents comparative study of geological parameters below Mainpat plateau, on Mainpat plateau and at Ultapani Bisarpani Village. Hygrometer reading was $32 \%$ and barometer reading was 29.60 inch $(75.18 \mathrm{~cm}) \mathrm{Hg}$ and atm. temp. was $80^{\circ} \mathrm{F}\left(37^{\circ} \mathrm{C}\right)$. The height of Mainpat plateau is $540 \mathrm{~m}$ as comparative reading in altitudes.

Table 1. Comparative study of geological parameters

\begin{tabular}{ccccccc}
\hline Sr. & Places & Magnetic field & Gravity & Altitude & Clinometers reading & Sextant reading \\
\hline 1 & Below Mainpat plateau & $45 \mu \mathrm{T}$ & $9.8067 \mathrm{~m} / \mathrm{S}^{2}$ & $579 \mathrm{~m}$ & $12^{0}$ & $101.6^{0}$ \\
2 & On Mainpat plateau & $47 \mu \mathrm{T}$ & $9.8067 \mathrm{~m} / \mathrm{S}^{2}$ & $1005 \mathrm{~m}$ & $9^{0}$ & $98.5^{0}$ \\
3 & At origin of Ultapani & $21 \mu \mathrm{T}$ & $9.8066 \mathrm{~m} / \mathrm{S}^{2}$ & $976 \mathrm{~m}$ & $0^{0}$ & $90.0^{0}$ \\
\hline
\end{tabular}

\subsection{Geomorphology of Ultapani}

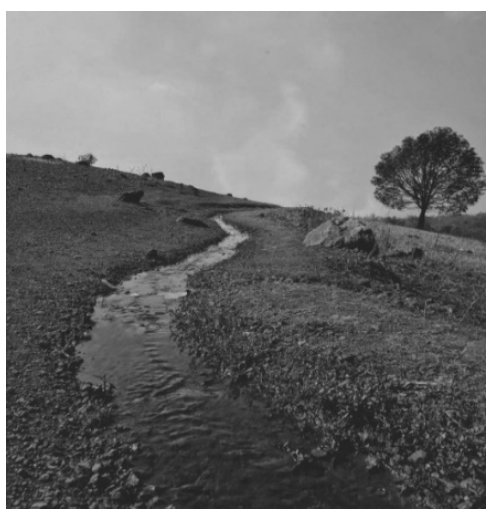

Figure 2. Uphill rise of Ultapani

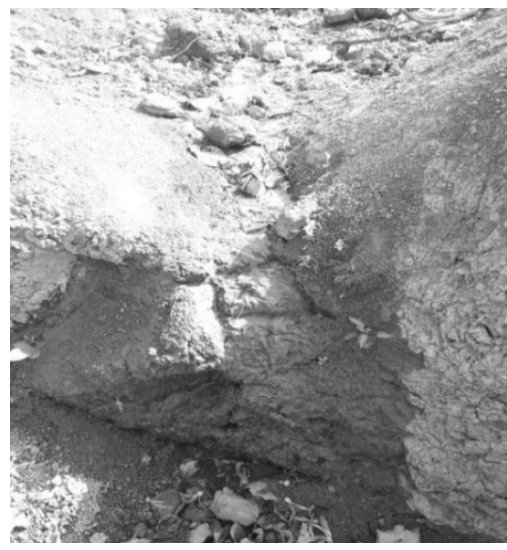

Figure 3. Decline of Ultapani

Ultapani is originated as a small spring from a deep ditch of $4.2 \mathrm{~cm}$ below a mango tree (Mengifera indica, Anacardiaceae). It flows west direction with the equivalent force of 6.0 gram weight. The depth of water level is $8.0 \mathrm{~cm}$ and flow velocity is $85 \mathrm{~cm}$ per minutes. After $1.5 \mathrm{~m}$ it flow upward by angle of $15.6^{\circ}$ and then it rises little by $1.2^{\circ}$ up to $25 \mathrm{~m}$, then it take a curve of $20^{\circ}$ north west side up to length of $75 \mathrm{~m}$. Then it curve toward west direction up to $70 \mathrm{~m}$, as shown in Figure 2. Then it curves toward south direction and rising up ends at $185 \mathrm{~m}$ length. Then it passes down through a pipe below road then flows downward in south direction with zero velocity stagnant and after $20 \mathrm{~m}$, it was dried, got absorbed and evaporated by hot summer of 40 degree temp as represented in Figure 3.

\section{OBSERVATION AND RESULT}

\subsection{Mainpat plateau}

Table 2. General Inspection of Ultapani

\begin{tabular}{|c|c|c|c|}
\hline Sr. & Inspection & Observation & Result \\
\hline 1 & $\begin{array}{l}\text { We poured drinking } \\
\text { water from summer } \\
\text { carry bag on } \\
\text { flowing Ultapani. }\end{array}$ & $\begin{array}{l}\text { The poured water } \\
\text { too ascents with } \\
\text { flowing water of } \\
\text { Ultapani. }\end{array}$ & $\begin{array}{l}\text { No effect of } \\
\text { water } \\
\text { chemistry. }\end{array}$ \\
\hline 2 & $\begin{array}{l}\text { We collected about } \\
200 \text { gram soil from } \\
\text { other place and } \\
\text { dropped on the } \\
\text { flowing Ultapani. }\end{array}$ & $\begin{array}{c}\text { Flowing water of } \\
\text { Ultapani continued } \\
\text { over the dropped } \\
\text { soil. }\end{array}$ & $\begin{array}{l}\text { No effect of } \\
\text { soil } \\
\text { chemistry. }\end{array}$ \\
\hline 3 & $\begin{array}{l}\text { We collected about } \\
300 \text { gram stone } \\
\text { from other place } \\
\text { and dropped on the } \\
\text { flowing Ultapani. }\end{array}$ & $\begin{array}{l}\text { Flowing water of } \\
\text { Ultapani continued } \\
\text { over and beside the } \\
\text { dropped stone. }\end{array}$ & $\begin{array}{l}\text { No effect of } \\
\text { rock } \\
\text { chemistry. }\end{array}$ \\
\hline
\end{tabular}

Table 2 represents comparative study of geological parameters below Mainpat plateau, on Mainpat plateau and at Ultapani Bisarpani village, the height of Mainpat plateau is $426 \mathrm{~m}$. There is difference of $2 \mu \mathrm{T}$ in magnetic field intensity in between below Mainpat land and on the Mainpat, $03 \mathrm{Km}$ before Ultapani. The average angle of Mainpat Plateau from low land is about $12^{\circ}$, while there is not any difference in gravity. 


\subsection{General inspection of Ultapani}

The testing of external water from summer carry bag and general inspection of Ultapani was done. Ascending of water flow upward to the hill is neither affected by soil chemistry nor by water chemistry. Ultapani is very small water spring which flows up ward, magnetic hill side with a serpent path, it is existing well in hot summer at $37^{\circ} \mathrm{C}$ to $41^{\circ} \mathrm{C}$ (twice explored on 20 may and 01 June 2019 . It is running up to $200 \mathrm{~m}$ hiking $185 \mathrm{~m}$, then flows toward slope, diffused and evaporated at end watering to human, birds and animals etc. of the village 'Bisarpani' meaning "Forget water".

\subsection{Geomorphology of Ultapani}

Measurement of angles of ascent of water flow was measured by sextant, by gonometer and digital slope meter. Table 3 represents geomorphology of the rise up of Ultapani; The electrical conductivity measurement of the Ultapani was done inserting the electrodes at the distance of $5 \mathrm{~cm}$ with Unitop Multimeter. Measurement of the length and depth was done with a meter tape.

Table 3. Geomorphology of Ultapani

\begin{tabular}{|c|c|c|c|c|c|c|}
\hline Sr. & Places of Ultapani & $\begin{array}{c}\text { Altimeters } \\
\text { reading }\end{array}$ & $\begin{array}{c}\text { Length from } \\
\text { origin }\end{array}$ & $\begin{array}{c}\text { Height from } \\
\text { origin }\end{array}$ & $\begin{array}{c}\text { Step } \\
\text { angle }\end{array}$ & $\begin{array}{c}\text { Conductivity } \\
\text { x20 } \mu \text { Rho } \\
\end{array}$ \\
\hline 1 & Starting point $15 \mathrm{~cm}$ from origin $\mathrm{A}$ & $976 \mathrm{~m}$ & $0.0 \mathrm{~m}$ & $0.0 \mathrm{~m}$ & $0.0^{0}$ & 2.60 \\
\hline 2 & Quarter length B & $985 \mathrm{~m}$ & $40 \mathrm{~m}$ & $6.0 \mathrm{~m}$ & $12^{0}$ & 2.71 \\
\hline 3 & Half length $\mathrm{C}$ & $986 \mathrm{~m}$ & $100 \mathrm{~m}$ & $10.0 \mathrm{~m}$ & $3.2^{0}$ & 2.00 \\
\hline 4 & Three fourth length D & $988 \mathrm{~m}$ & $140 \mathrm{~m}$ & $12.0 \mathrm{~m}$ & $1.8^{0}$ & 2.21 \\
\hline 5 & End point- E & $1005 \mathrm{~m}$ & $185 \mathrm{~m}$ & $14.0 \mathrm{~m}$ & $2.4^{0}$ & 2.00 \\
\hline
\end{tabular}

Table 4. Hydrology of Ultapani

\begin{tabular}{cccccccc}
\hline Sr. & Places of Ultapani & $\begin{array}{c}\text { Flow } \\
\text { velocity }\end{array}$ & $\begin{array}{c}\text { Flow } \\
\text { perimeter }\end{array}$ & $\begin{array}{c}\text { Depth of } \\
\text { flow }\end{array}$ & $\begin{array}{c}\text { Total Height } \\
\text { of walls }\end{array}$ & $\begin{array}{c}\text { Force of flow, in } \\
\text { Weight }\end{array}$ & $\begin{array}{c}\text { Calculated } \\
\text { Hydrological force in } \\
\text { dyne }\end{array}$ \\
\hline 1 & Starting point A & $85 \mathrm{~cm} / \mathrm{m}$. & $34 \mathrm{~cm}$ & $8 \mathrm{~cm}$ & $2 \mathrm{~cm}$ & $6.00 \mathrm{gram}$ & $53928 \times 10^{15}$ \\
2 & Quarter length B & $80 \mathrm{~cm} / \mathrm{m}$ & $27 \mathrm{~cm}$ & $4 \mathrm{~cm}$ & $11 \mathrm{~cm}$ & $5.30 \mathrm{gram}$ & $47636 \times 10^{15}$ \\
3 & Half length C & $65 \mathrm{~cm} / \mathrm{m}$ & $25 \mathrm{~cm}$ & $6 \mathrm{~cm}$ & $5 \mathrm{~cm}$ & $4.20 \mathrm{gram}$ & $37749 \times 10^{15}$ \\
4 & Three fourth length D & $50 \mathrm{~cm} / \mathrm{m}$ & $22 \mathrm{~cm}$ & $6 \mathrm{~cm}$ & $10 \mathrm{~cm}$ & $2.65 \mathrm{gram}$ & $23818 \times 10^{15}$ \\
5 & End point E & $26 \mathrm{~cm} / \mathrm{m}$ & $18 \mathrm{~cm}$ & $5 \mathrm{~cm}$ & $19 \mathrm{~cm}$ & $1.20 \mathrm{gram}$ & $10785 \times 10^{15}$ \\
6 & On decline post rise & $0.0 \mathrm{~cm} / \mathrm{m}$ & $0.0 \mathrm{~cm}$ & $0.0 \mathrm{~cm}$ & $25 \mathrm{~cm}$ & $0.0 \mathrm{gm}$ & 0.0 \\
\hline
\end{tabular}

Table 5. Geophysics of Ultapani

\begin{tabular}{|c|c|c|c|c|c|c|}
\hline Sr. & Place at distance from origin of U.P. & Magnetic field & Gravity & Altitude & $\begin{array}{c}\text { Clinometers' } \\
\text { reading }\end{array}$ & Sextant reading \\
\hline 1 & Before Ultapani (-185m) & $45 \mu \mathrm{T}$ & $9.8067 \mathrm{~m} / \mathrm{S}^{2}$ & $1005 \mathrm{~m}$ & $-3.5^{0}$ & $86.4^{0}$ \\
\hline 2 & Before Ultapani (-140m) & $46 \mu \mathrm{T}$ & $9.8067 \mathrm{~m} / \mathrm{S}^{2}$ & $1016 \mathrm{~m}$ & $-1.6^{0}$ & $88.0^{0}$ \\
\hline 3 & Before Ultapani $(-40 \mathrm{~m})$ & $44 \mu \mathrm{T}$ & $9.8067 \mathrm{~m} / \mathrm{S}^{2}$ & $996 \mathrm{~m}$ & $-3.0^{0}$ & $86.5^{0}$ \\
\hline 4 & Origin of Ultapani $(00.00 \mathrm{~m})$ & $21 \mu \mathrm{T}$ & $9.8066 \mathrm{~m} / \mathrm{S}^{2}$ & $976 \mathrm{~m}$ & $0.0^{0}$ & $0.0^{0}$ \\
\hline 5 & $40 \mathrm{~m}$ length of Ultapani & $32 \mu \mathrm{T}$ & $9.8067 \mathrm{~m} / \mathrm{S}^{2}$ & $991 \mathrm{~m}$ & $12.1^{0}$ & $112.0^{0}$ \\
\hline 6 & $100 \mathrm{~m}$ length of Ultapani & $38 \mu \mathrm{T}$ & $9.8067 \mathrm{~m} / \mathrm{S}^{2}$ & $993 \mathrm{~m}$ & $4.5^{0}$ & $95.0^{0}$ \\
\hline 7 & $140 \mathrm{~m}$ length of Ultapani & $43 \mu \mathrm{T}$ & $9.8067 \mathrm{~m} / \mathrm{S}^{2}$ & $995 \mathrm{~m}$ & $4.5^{0}$ & $96.0^{0}$ \\
\hline 8 & $185 \mathrm{~m}$ length, end point of Ultapani & $50 \mu \mathrm{T}$ & $9.8067 \mathrm{~m} / \mathrm{S}^{2}$ & $1005 \mathrm{~m}$ & $3.2^{0}$ & $93.0^{0}$ \\
\hline 9 & $230 \mathrm{~m}$ distance from origin (After end of UP) & $45 \mu \mathrm{T}$ & $9.8067 \mathrm{~m} / \mathrm{S}^{2}$ & $942 \mathrm{~m}$ & $-2.2^{0}$ & $88.0^{0}$ \\
\hline 10 & $270 \mathrm{~m}$ distance from origin (After end of UP) & $46 \mu \mathrm{T}$ & $9.8067 \mathrm{~m} / \mathrm{S}^{2}$ & $930 \mathrm{~m}$ & $-4.5^{0}$ & $86.3^{0}$ \\
\hline 11 & $320 \mathrm{~m}$ distance from origin (After end of UP) & $47 \mu \mathrm{T}$ & $9.8067 \mathrm{~m} / \mathrm{S}^{2}$ & $920 \mathrm{~m}$ & $-6.4^{0}$ & $84.5^{0}$ \\
\hline
\end{tabular}

\subsection{Hydrology of Ultapani}

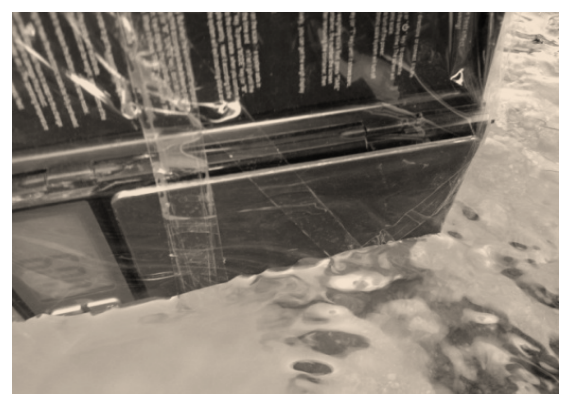

Figure 4. Mini weight hand book 500gram measuring flow power
Table 4 represents the hydrological parameters. Figure 4 represents the force applied by Ultapani to flow water against gravity up to $14.0 \mathrm{~m}$. It was found to be equivalent force of 6.00 gram weight.

\subsection{Up rise force}

Given in Clark's table Science data book (pp 80):

$01 \mathrm{~kg}=8.988 \times 10^{16}$ Joule Or 1,000 gram $=8.988 \times 10^{16}$ Joule 06 gram $=6 \times 8.988 \times 10^{16} / 1000$ Joule $=53928 \times 10^{10}$ Joule $=53928 \times 10^{17}$ Erg $=53928 \times 10^{15}$ Dyne 


\subsection{Geophysics of Ultapani}

Table 5 represents the measurement of geophysical parameters at very hot summer season, when about all small seasonal rivers dried by atmospheric temp. between $37^{\circ} \mathrm{C}$ to $410 \mathrm{C}$. Hygrometer reading was $32 \%$ and barometer reading was 29.6 inch $\mathrm{Hg}$.

\section{DISCUSSION}

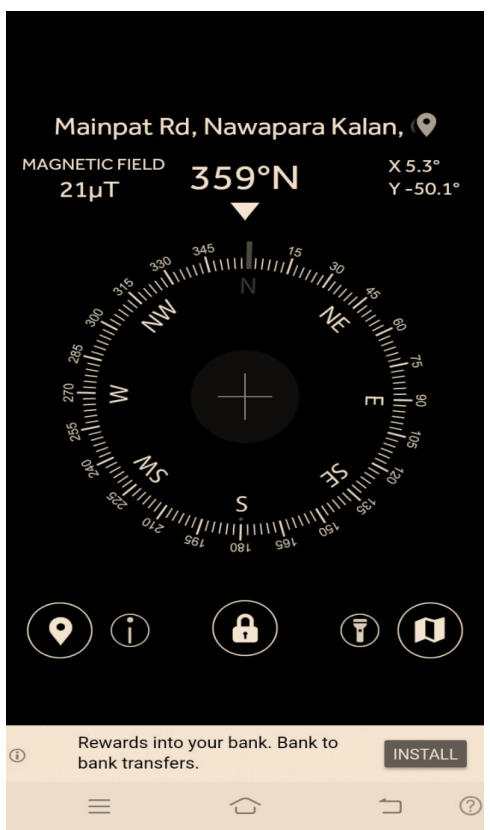

Figure 5a. Magnetic compass at origin of U.P

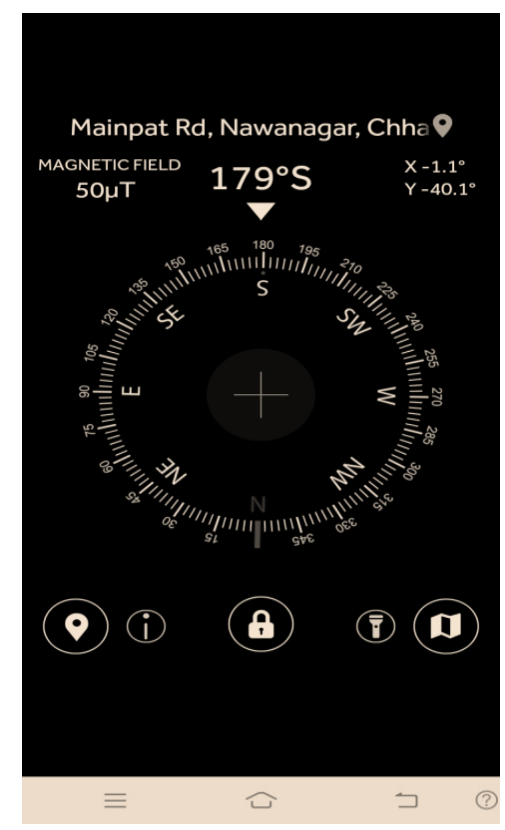

Figure 5b. Magnetic compass at end of U.P

Opposite flow of Ganga river in Figure 6, is due to an ocean wave pressure, but here in Ultapani, it seemed to be by the magnetic field intensity gradient of magnetic hill. This, as in Figure $5 \mathrm{a}$ and Figure $5 \mathrm{~b}$, difference was more than double. This change could be due to absent of hematite and increasing from $21 \mu \mathrm{T}$ to $50 \mu \mathrm{T}$ from origin to end. Therefore, it is a magnetic hill. There is at origin $21 \mu \mathrm{T}$ but on the end of Ultapani is $50 \mu \mathrm{T}$. By this difference, the water flow with the force of $53928 \times 10^{15}$ dyne. Nature has mystery and there is need of further study, since magnetic field may change due to solar waves, seasonal rotation of earth, diurnal rotation of earth, inter planetary attraction relationship.

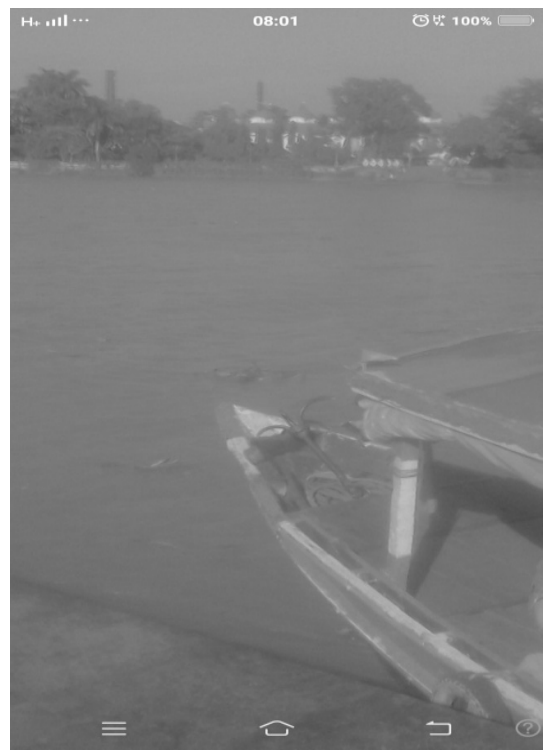

Figure 6. Opposite flow of Ganga at Kolkata

\subsection{Trigonometry of Ultapani}

By the angle of $12^{\circ}$ Ultapani rises to upward, If Origin point is $\mathrm{A}$ and after opposite anti gravity flow end point of Ultapani is point $\mathrm{C}$. where $\mathrm{CB}$ is $14 \mathrm{~m}$. by altitude difference between origin and end of Ultapani. Pythagoras principle is hypotenuse $2=$ base $^{2}+$ vertex $^{2}$

$$
\begin{gathered}
(185)^{2}=(\mathrm{AB})^{2}+(14)^{2} \\
\text { Or }(\mathrm{AB})^{2}=(185)^{2}-(14)^{2} \\
(\mathrm{AB})^{2}=34225-196 \\
\text { Or } \mathrm{AB}=\text { under root of } 34029 \\
\mathrm{AB}=184.47 \mathrm{~m} \\
\text { Therefore }(185)^{2}=(184.47)^{2}+(14)^{2} \\
34225=34029+196, \text { thus verified. }
\end{gathered}
$$

Tan theta base, should be the height of Ultapani, the total of angles rising up water flow up to $185 \mathrm{~m}$, then downward flows. The total of positive steep angles and negative slopes angles measured by slope meter. The sum of all angles in table 5 column 6 slope meters is:

$$
\begin{aligned}
& (+24.3)^{0}+(-20.90)^{0}=3.4^{0} \\
& \text { Tan } 3.4^{0}=0.05941094706
\end{aligned}
$$

$0.05941094706 \times 184.47=11 \mathrm{~m}$. The calculated height to ascent water flow is $11 \mathrm{~m}$, while measured height is $14 \mathrm{~m}$; the difference of $3 \mathrm{~m}$ height is error of angle measurement.

\subsection{Concept of gravity holes of the earth}

Opposite to chemistry of Tintina stone [13], Flying stone [9] is total burned mars meteorite's melted ash, when fell to the earth, it jumped to be suspended on air as it has a flat lower surface in its texture, as depicted in Figure 7 and 8 . There are 
gravity holes on the earth where the suspended stones are found [10]. Such gravity hole could be Ultapani, although gravity difference is negligible, the difference is $0.0001 \mathrm{~m} / \mathrm{s}^{2}$ to be negligible.

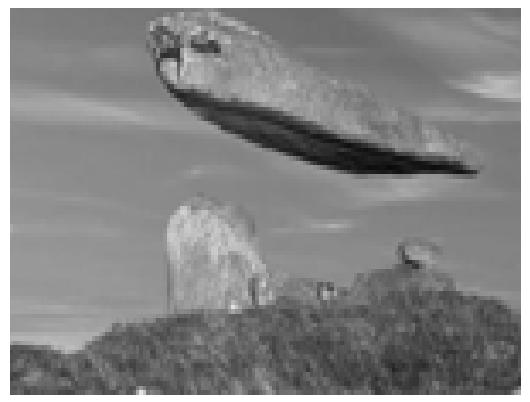

Figure 7. Suspended stone1

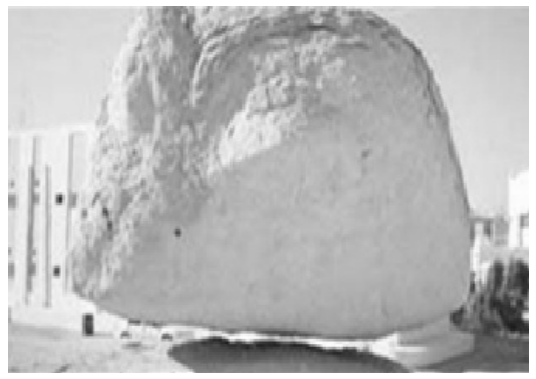

Figure 8. Suspended stone2

\subsection{Concept of astrophysical force}

Our earth is at about median position of planetary solar system, and our solar system is at about median position of Milky Way. The gravity of Milky Way G' is feeble due to high solar system's G gravity, and the earth's gravity is g. There is also an attraction between objects termed as cohesion and adhesion force, the magnetic attraction of hill is g'. There is an interaction between $\mathrm{G}$, $g$ and g', and resultant gravity may be a cause to ascent water flow toward step of hill [30].

Solar angle of earth is time and solar energy of gravity helps to ascent water in Ultapani. Second law of times is law of opposite, providing theory for opposite force of astral time line; It may be a cause of opposite water flow. Ultapani is specific geophysics, as well as, astrophysics to ascent up water flow. Gravity of the solar system $\mathrm{G}$ is responsible. But how to prove? Since, at Ultapani a miracle happened, to be observations opposite, author got confused when visited twice, therefore, thought of opposite flow by force of time line [31].

There might be also a relation with the River Narmada, originated from Amarkantak MP, about $150 \mathrm{Km}$ far from Ultapani, which is uncommon to flow toward west direction, likewise Ultapani. Microscopic longitude and latitude of the earth and of the solar system should be examined and theirs affected resultant gravity should be more or equal to earth's gravity force. Because problem here was that, magnetic field intensity force $(\mu \mathrm{T})$ of the earth fluctuate to more than double but gravity doesn't change.

\subsection{Bernoulli principle}

Since, river science has a law i.e. width of river is in proportion with length and flow toward slope. But here is gradual decreasing width of Ultapani to flow toward steep. Its geo morphology is help full to follow Bernoulli principle, $\mathrm{p}_{1} \mathrm{v}_{1}=\mathrm{p}_{2} \mathrm{v}_{2}$, in table 4 column3, width of Ultapani decreases gradually from 34 to $18 \mathrm{~cm}$. Water stagnates but there is passage to upward flow by adhesion and-cohesion forces between water molecules and between soil particles and water molecules.

\subsection{Specific geo diversity}

There are many mysterious geo diversity. e.g. Jatinga, a birds suicide place [28], 03 days in each year in July, flow of red water from Shri Kamaksha Temple Assam (29), singing stone and musical stone [13], suspended stones [9, 10], heartbeat of earth[14], opposing flow of Ganga [8], opposite glacier flow [6], snake land [17] etc. Ultapani is one of them a natural miracle created by difference of geo magnetic field intensity [27].

\subsection{Further scope of the study}

Science is diversified; Ethics is that, Ultapani is manmade, 200 years before such a way for social services of hydrology for water supply. Some scientists can study Ultapani pure mathematically applying sine theta and tangent law to calculatem force applied by Ultapani [18-20]. One can calibrate a geodetic sensor for metal detection inside earth causing magnetic field [21-23] There are intelligence applications in these areas of study [24-26] Study of magnetic field could be done [27]. It is not any scope, of course, in zoology, since, even a fish was unseen. While, there are full hydrophytes herbs in Ultapani. River Ganga if, in deep flows southward to Bay of Bengal, by river's hydrological force. But on surface it flows northward to temple by ocean wave force. Therefore, at the middle line of both opposite currents, the difference for the floating material or swimming organism could be of an interest [8].

\section{CONCLUSION}

Ultapani is opposite water flow rising to a magnetic hill up to $185 \mathrm{~m}$ due to magnetic intensity gradient from $21 \mu \mathrm{T}$ to 50 $\mu \mathrm{T}$. Also, it could be due to specific geo morphology following Bernoulli principle with the force of $53928 \times 10^{17}$ Erg or 53928 $\mathrm{x} 10^{15}$ Dyne. Electromagnetic properties of water are described in ref.32. Ultapani is just out of the perimeter of Indian snake land Tapkara; therefore, it is suggested to visit with precaution. November to June is good time to visit Ultapani [17].

\section{REFERENCES}

[1] Gray, M. (2017). Geo diversity: 'Valuing and Conserving Abiotic Nature'. John Wiley \& Sons Ltd, Chichester. https://en.wikipedia.org/wiki/Geodiversity\#mw. Retrieved 30 May 2017.

[2] https://en.wikipedia.org/wiki/Ultapani_Reserve_Forest. Retrieved 30 May 2019

[3] Ultapani Forest Block Village in Kokrajhar (Kokrajhar) Assam villageinfo.in. Villageinfo.in.Retrieved 30 May 2019

[4] Publication (PDF): Diversity and Conservation of Ultapani Reserve Forest of Assam: Problems and 
Prospects. Research Gate. Retrieved 30 May 2019

[5] https:/www.ibtimes.co.in/can-river-flow-uphill-if-itsantarctica-it-looks-like-it-certainly-can-720972 Retrieved 30 May 2019

[6] Lieser, J.L. (2017). Mysterious green ice spotted in Antarctica by NASA's Operational Land Imager! International Business Times, IBTimes.com, India, 15 March, 2017. [Media Interview] Rhttp://ecite.utas.edu.au/115313 Retrieved 30 May 20199

[7] https://www.ibtimes.co.in > Science > Space Retrieved 30 May 2019

[8] River Ganga flow in opposite direction near Dakshineswar Temple-picfoks video https://www.youtube.com/watch?v=I_m-TerzDpo. Retrieved 30 May 2019

[9] https://www.google.com/search?q=flying+stones\&tbm= isch\&source $=$ iu\&ict $=1 \&$ fir $=\mathrm{x} 5 \mathrm{t} 2 \mathrm{KxbWxK} 1 \mathrm{iyM} \% 253$ A\%252CtwxYwmA8nlkQqM\%252C_\&vet=1\&usg=AI 4 -

kS61xblACVQSbtiafUwAw3ogE34CQ\&sa=X\&ved=2a hUKEwio_tuxyc3iAhWlyoUKHZjZCxwQ9QEwAHoE CAUQBA\&biw $=1020 \&$ bih $=495 \#$ imgrc $=x 5 \mathrm{t} 2 \mathrm{KxbWxK}$ 1iyM:\&vet $=1$ Retrieved on 01 June 2019

[10] https://www.google.com/search?q=flying+stone+at+aj mer + shareef $\&$ tbm $=i$ sch \&source $=i u \& i c t x=1 \&$ fir $=r p 5 T N$ J8eW9Y4YM Retrieved on 01 June 2019

[11] https://www.google.com/maps/@22.8728379,83.29573 $94,5652 \mathrm{~m} /$ data $=! 3 \mathrm{~m} 1 ! 1 \mathrm{e} 3 ! 5 \mathrm{~m} 1$ ! $1 \mathrm{e} 4$ Retrieved on 01 June 2019

[12] https://www.google.com/maps/place/Ulta+Pani+Visarp ani/@22.8786266,83.2811791, $535 \mathrm{~m} / \mathrm{data}=! 3 \mathrm{~m} 1 ! 1 \mathrm{e} 3 ! 4 \mathrm{~m} 12 ! 1 \mathrm{~m} 6 ! 3 \mathrm{~m}$ Retrieved on 01 June 2019

[13] Mahar, H.D. (2015). Divya Mahar and Durgesh Mahar
Biodiversity and Mars Meteorite Analog of Tintina Stone at Darima, Ambikapur, Surguja CG, India. AMSE Journals -2015-Series: Modeling C, 76(1): 46-58.

[14] Mahar, H.D., Mahar, D., Mahar, D. (2017). Biogeography and Volcano Crater Analogy of Swinging land, Jaljali, Mainpat Plateau, Surguja, C.G, India AMSE Journals-AMSE IIETA publication-2017-Series: Modeling C, 78(4): 444-454.

[15] Mahar, H.D., Mahar, D., Mahar, D. (2015). Measurement of Height and Satellite Imaging of 'Siddh Baba Hill' at Manendragarh, Dist. Korea, C. G. India. AMSE Journals -2015-Series: Modeling C, 76(1): 59-71.

[16] https://www.google.com/search?q=gravity+holes\&tbm $=$ isch \&source $=$ univ $\&$ sa $=X \& v e d=2$ ahUKEwiwqcDZ4s iAhWLyYUKHYfjCM4QsAR6BAgEEAE\&biw $=1008$ \&bih=534 Retrieved on 01 June 2019

[17] Mahar, H.D., Mahar, D., Mahar, D., Jhariya, M.K., Jaiswal, R.K., Agrawal, A. (2017). Biogeography of Bangarus carcerulus in Snake Land-Tapakara, Jashpur, Surguja, CG, Indi. AMSE Journals-AMSE IIETA Publication-2017, Modeling C, 78(4): 417-429.

[18] Reda, R., Fayçal, A., Tahar, B. (2017). Fault Eccentricity Diagnosis in Variable Speed Induction Motor Drive Using DWT. AMSE Journals, Series: Modeling C, 72(3): 181-202.

[19] Zhang, Z., Guo, J.H., Yu, W. (2017). Sedimentary Reflection of Tectonic Activities of Fault Depression Basin-taking Lufeng Depression as an Example. AMSE Journals Modeling C, 78(2): 191-209.

[20] Hasim, R., Jaiswal, A., Shrivastva, B.K. (2018). Estimation of rock load height during development operation in board and pillar coal mine using numerical simulation method. AMSE Journals Modelling C, 79(2): 24-35. 